\title{
Seasonal response of edaphic bioindicators using green manure in Brazilian semi-arid conditions ${ }^{1}$
}

\author{
Sazonalidade de resposta de bioindicadores edáficos utilizando adubação verde no \\ semi-árido brasileiro
}

\author{
Márcio Sampaio Pimentel ${ }^{2 *}$, Rubens Silva Carvalho ${ }^{3}$, Lindete Míria Vieira Martins ${ }^{3}$ e Adriano Victor Lopes da \\ Silva ${ }^{4}$
}

\begin{abstract}
The goal of this work was to evaluate the response of edaphic macrofauna, soil microbial biomass carbon, soil basal respiration, metabolic quotient and labile carbon of fumigated soil in a Fluvic Neosol. The experimental design was in randomized blocks, with five treatments (four green manure mix and one control) and four replications, and subsequent planting of melon (Cucumis melo L.) under semi-arid conditions in Juazeiro, Bahia State, Brazil, from August 2006 to August 2007. Soil samples were collected at a depth of $0-10 \mathrm{~cm}$ at 6 days before, and $117 ; 215$ and 354 days after green manure mix planting. The results indicate that none of the attributes presented a significant difference for the treatments, but changed significantly in relation to the time of sample collection. The higher levels of soil microbial biomass carbon and labile carbon of fumigated soil were measured 117 days after planting. Soil microbial biomass carbon was inversely correlated with soil basal respiration and metabolic quotient, which increased as of 215 days after planting. At 354 days after planting, the edaphic macrofauna presented the highest density, richness, diversity and uniformity. Ants and beetles were most abundant in the areas studied.
\end{abstract}

Key words - Soil quality. Macrofauna edaphic. Plant biomass. Plant mixture. Caatinga forest.

\begin{abstract}
Resumo - O objetivo deste trabalho foi avaliar a resposta da macrofauna edáfica, carbono da biomassa microbiana, respiração do solo, quociente metabólico e carbono lábil de solo fumigado em Neossolo Flúvico. O delineamento experimental foi em locos ao acaso com cinco tratamentos (quatro combinações de coquetéis vegetais e testemunha) e quatro repetições, e subseqüente plantio de melão na região semi-árida de Juazeiro, Bahia, Brasil, entre os meses de agosto de 2006 a agosto de 2007. Foram realizadas quatro coletas de solo na profundidade de $0-10 \mathrm{~cm}$ aos: seis dias antes do plantio do coquetel vegetal, 117; 215 e 354 dias após plantio do coquetel vegetal. Os resultados obtidos indicam que todos os atributos não apresentaram diferença significativa para os tratamentos com coquetel vegetal, mas diferiram significativamente em função da época da coleta. Maiores teores de carbono da biomassa microbiana e carbono lábil de solo fumigado foram obtidos aos 117 dias após o plantio. Carbono da biomassa microbiana correlacionou-se inversamente à respiração do solo e ao quociente metabólico, que aumentaram a partir de 215 dias após plantio. Aos 354 dias após plantio, a macrofauna edáfica apresentou maior densidade, riqueza, diversidade e uniformidade, tendo formigas e besouros sido os animais mais abundantes.
\end{abstract}

Palavras-chave - Qualidade do solo. Macrofauna edáfica. Biomassa vegetal. Coquetel vegetal. Caatinga.

\footnotetext{
*Autor para correspondência

${ }^{1}$ Recebido para publicação em 02/10/2010; aprovado em 09/05/2011

Parte do Trabalho de bolsa PRODOC/FAPESB do primeiro autor

${ }^{2}$ Colegiado de Agronomia, Universidade Federal do Vale do São Francisco/UNIVASF/CCA, Campus Ciências Agrárias, Rod. BR 407 Km 12, Lote

543 Projeto de Irrigação Senador Nilo Coelho, s/no, $\mathrm{C} 1 ; 56.300-000 ;$ Petrolina-PE, Brasil, marcio.pimentel@univasf.edu.br

${ }^{3}$ Departamento de Tecnologia e Ciências Sociais, DTCS/Universidade do Estado da Bahia/UNEB, Av. Edgard Chastinet S/N, São Geraldo, 48.900-

000, Juazeiro-BA, Brasil, rusilca@ig.com.br, mirialind@yahoo.com.br

${ }^{4}$ Colegiado de Agronomia, UNIVASF, Petrolina-PE, Brasil, adriano.victor@univasf.edu.br
} 


\section{Introduction}

Studies regarding the edaphic bioindicators in Brazilian semi-arid conditions are still quite scarce, a reflection of the great lack of interest in tropical dry forests, even though they are considered to be one of the most threatened ecosystems on the planet (JANZEN, 1997). This biome is characterized by high temperatures and rate of evaporation, poorly distributed rainfall, shallow soils and intense surface runoff (ALMEIDA-CORTEZ et al., 2007).

In irrigated areas, such as those that are installed in the municipality of Juazeiro, Bahia State, Brazil, a highly technical agriculture has been developed, with a strong presence in the domestic and foreign commercial markets, due to the favorable ecological conditions and availability of land area (PASSOS et al., 2004). The region stands out in the production of mangoes, grapes and melons, driven by ever-increasing demands from consumers in Brazil and abroad (MARTINS, 2003).

The environment is not infinite in its capacity for absorbing the different impacts caused by man (ALMEIDA et al., 2000) and, in agriculture, the use of inputs and techniques can lead to biological erosion, degradation and salinization of soils. Under such limiting conditions, it is important to adopt management practices that help in the improvement of soil quality, such as organic fertilization, mulching, crop rotation, intercropping and green manure crops for the chemical, physical and biological improvement of the soil conditions.

The interaction among chemical, physical and biological agents regulates a large part of the conditions required by the plant and which mold soil fertility (PIMENTEL, 2005). Organic residues deposited in the soil are essential to the process of addition of organic carbon (DORAN, 1980) and increase of soil organic matter.

Considering that good management and conservation practices are directly associated with the maintenance of soil quality, defined as the capacity of tending to the requirements for biological sustainability and productivity, maintenance of the environmental quality and promotion of plant and animal health (DORAN, 2002), it is important to have attributes available that can assist in the measurement of this quality. In this sense, edaphic macrofauna (HERDJANIA et al., 2007), soil microbial biomass (FRANCHINI et al., 2007; SOUZA et al., 2008), soil basal respiration (SILVA et al., 2007), metabolic quotient (SILVA et al., 2007) and labile carbon (SOUZA et al., 2008; ZOU et al., 2005) have stood out in the indication of changes promoted by soil management in agroecosystems.

In Brazil, the number of studies regarding soil fauna is irrelevant before the diversity of ecosystems and the lack of knowledge of the soil diversity itself. The goal of this work was to evaluate the response of edaphic macrofauna, soil microbial biomass carbon, soil basal respiration, metabolic quotient and labile carbon of fumigated soil in semi-arid soil conditions subjected to a prior green manure crop using green manure mix and posterior melon cropping.

\section{Material and methods}

In an area of the experimental field of the State University of Bahia located in the municipality of Juazeiro, Bahia State, Brazil, were evaluated edaphic macrofauna, soil microbial biomass carbon, soil basal respiration, metabolic quotient and labile carbon of fumigated soil, from August 2006 to August 2007, in soil subjected to the succession of a green manure mix by melon.

The region is located at $9^{\circ} 25^{\prime}$ south and $40^{\circ} 29^{\prime}$ east, at an altitude of $366 \mathrm{~m}$, climate BSh (Köppen) characterized by a mean annual temperature maximum of $29.6{ }^{\circ} \mathrm{C}$ and minimum of $20.3{ }^{\circ} \mathrm{C}$ and a rainfall between 250 and $500 \mathrm{~mm}$ distributed from November to March. The highest temperatures occur during the months of January and February, while the lowest monthly average occurs in the months of June and July. Figure 1 shows the average monthly distribution of rains in the period monitored, with the arrows indicating soil sample collections.

Soil tillage was performed through deep subsoiling, plowing, harrowing and delimitation of the test area into $8 \times 8 \mathrm{~m}$ plots. The soil is a Fluvic Neosol with a clay sandy loam texture with $29.0 \%$ sand, $22.1 \%$ silt and $48.9 \%$ clay. Before the experiment, chemical analyses of the soil plots presented the following result: $\mathrm{pH}$ (water) $6.5 ; 0.0 \mathrm{cmol} \mathrm{dm}^{-3}$ of $\mathrm{Al} ; 5.7 \mathrm{cmol} \mathrm{dm}^{-3}$ of $\mathrm{Ca} ; 2.0 \mathrm{cmol}_{\mathrm{c}} \mathrm{dm}^{-3}$ of $\mathrm{Mg} ; 21.0 \mathrm{mg} \mathrm{kg}^{-1}$ of $\mathrm{P} ; 23.5 \mathrm{mg} \mathrm{kg}^{-1}$ of $\mathrm{K} ; 7.7 \mathrm{~g} \mathrm{~kg}^{-1}$ of organic $\mathrm{C}$ and $13.3 \mathrm{~g} \mathrm{~kg}^{-1}$ of organic matter (EMBRAPA, 1997).

The green manure mix was planted in August 2006 , by the method of broadcast seeding, with a mechanical harvest being performing at 90 days. The planting of melon (Cucumis melo L.) hybrid AF-684 was performed in April 2007. The spacing used in the melon crop was $0.40 \mathrm{~m}$ between plants and $2.0 \mathrm{~m}$ between rows, for a total of 12,500 plants ha ${ }^{-1}$ with drip irrigation in association with the varieties selected for composition of the green manure mixtures, except for the conventional tillage treatment. The melon harvest occurred in July 2007.

The experimental design was in randomized blocks with five treatments (four green manure mixes and one control) and four replications, totaling 20 plots of $64 \mathrm{~m}^{2}$ each one. The species that composed the green 


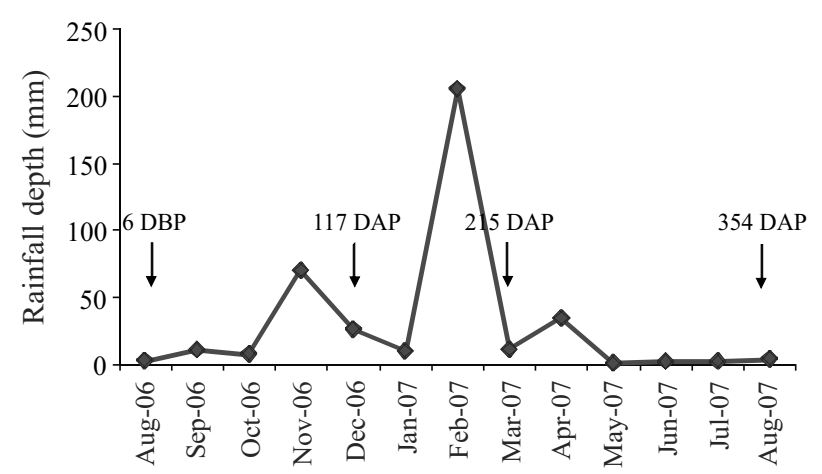

Figure 1 - Rainfall distribution during the green manure mixmelon crop succession in the municipality of Juazeiro, Bahia State, Brazil. Arrows represent the months in which soil samples were collected 6 days before planting (DBP), 117, 215 and 354 days after planting (DAP)

manure mixes were: T1: Control. T2 and T3: Zea mays L., Pennisetum glaucum, Sorghum bicolor L., Mucuna nivea, Crotalaria spectabilis, Leucaeana leucocephala, Canavalia ensiformis. T4 and T5: Helianthus annuus, Ricinus communis L., Z. mays L., M. nivea, Canavalia ensiformis, L. leucocephala, Vigna unguiculata L., Crotalaria spectabilis, Cajanus cajan, Dolichos lab lab, Crotalaria juncea, Mucuna aterrina, S. bicolor L. In treatments T3 and T5, the seeds of the legumes were inoculated with bacteria of the Rhizobium genus.

The soil samples for edaphic macrofauna, soil microbial biomass carbon, soil basal respiration, metabolic quotient and labile carbon of fumigated soil were collected in the center of each plot at a depth of $0-10 \mathrm{~cm}$ at 6 days before in August 2006 and at 117, 215 and 354 days after green manure mix planting in December 2006, March 2007 and August 2007, respectively.

For the edaphic macrofauna, two monoliths were taken in a randomized way from the center of each plot in each of the four replications, totaling eight monoliths per treatment. The monoliths were made with a surface of $25 \mathrm{~cm} \times 25 \mathrm{~cm}$, using the method recommended by the Tropical Soil Biology and Fertility Program (ANDERSON; INGRAM, 1993). The individual edaphic macrofauna with a length greater than $10 \mathrm{~mm}$ were removed manually and stored in bottles containing $70 \%$ alcohol for preservation and later identification at the level of the large taxonomic groups and counting under a stereoscopic microscope. For this study, the term "group" was used to mean class, order or family. The communities were characterized as based on: a) average density, expressed in number of individuals by square meter, b) average richness, meaning number of groups per monolith, c) uniformity and d) diversity (Shannon index). The Shannon diversity index was obtained by the ratio $\left(\mathrm{H}=-\sum \mathrm{p}_{\mathrm{i}} \ln \mathrm{p}_{\mathrm{i}}\right)$, in which: $\mathrm{p}_{\mathrm{i}}=$ $\mathrm{n}_{\mathrm{i}} / \mathrm{N} ; \mathrm{n}_{\mathrm{i}}$ is the density of each group; $\mathrm{N}$ is the total number of groups (MAGURRAN, 1988).

For soil microbial biomass carbon, soil basal respiration, metabolic quotient and labile carbon of fumigated soil, six simple samples were collected in the plots for removal of a composite sample. Then the soil samples were broken up and homogenized for weighing and immediately analyzed. The evaluation of the soil microbial biomass carbon was performed based on the fumigation extraction method, modified from DePolli and Guerra (2008). The soil basal respiration was measured according Stotzky (1965) and metabolic quotient was calculated from the ratio between the carbon respired per unit of microbial carbon in a time interval (ANDERSON; DOMSCH, 1990). The labile carbon of the fumigated soil was used for the estimation of soil microbial biomass carbon according to the methodology of De-Polli and Guerra (2008).

We conducted an analysis of variance to detect how the attributes changed in response to the green manure mix over the period of sample collection, along with a mean comparison test using Tukey's test, which serves as a complement for the study of analysis of variance to differentiate the collection time. The multivariate techniques of principal component analysis (PCA) and cluster analysis were used to better visualize these differences between the means of the attributes in relation to microbial attributes, ecological attributes and edaphic macrofauna. PCA was used to verify the dispersion of soil microbial biomass carbon, soil basal respiration, metabolic quotient, labile carbon of fumigated soil, density, richness, diversity and uniformity of the edaphic macrofauna (FIG. 1, arrows) in terms of the time of sample collections (numbers). In the case of the PCA, the data was standardized using self scaling so that each piece of data has the same weight. All analyses were made using the statistical program R, version 2.9.1 (R DEVELOPMENT CORE TEAM, 2009).

\section{Results and discussion}

The results indicate that soil microbial biomass, soil basal respiration, metabolic quotient, labile carbon of fumigated soil, density, richness, diversity and uniformity of the edaphic macrofauna did not show significant differences for the treatments using green manure mix, but differed significantly with the time of sample collection (TAB. 1).

Soil microbial biomass carbon showed an increase at 117 days after planting but decreased at 215 and 354 days after planting. Up to 117 days after planting, it is probable that the improvements coming from the use of 
Table 1 - Mean values of soil microbial biomass carbon (SMBC) $\left(\mathrm{mg} \mathrm{C} \mathrm{kg}^{-1}\right.$ soil), labile carbon of fumigated soil ( $\left.\mathrm{LC}_{\mathrm{f}}\right)\left(\mathrm{mg} \mathrm{C} \mathrm{kg}^{-1} \mathrm{soil}\right), \mathrm{soil}$ basal respiration (SBR) (mg C-CO $\mathrm{kg}^{-1}$ soil h $\left.\mathrm{h}^{-1}\right)$, metabolic quotient $\left(\mathrm{qCO}_{2}\right)\left(\mathrm{mg} \mathrm{C}-\mathrm{CO}_{2} \mathrm{~g}^{-1} \mathrm{Cmic}^{-1} \mathrm{~h}^{-1}\right.$, average density (DEN) (ind $\left.0.25 \mathrm{~m}^{-2}\right)$, richness (RICH), diversity (DIV) and uniformity (UNIF) of edaphic macrofauna during the green manure mix-melon crop succession in the municipality of Juazeiro, Bahia State, Brazil

\begin{tabular}{lrrrrrrrr}
\hline Collection & \multicolumn{1}{c}{ SMBC } & \multicolumn{1}{c}{$\mathrm{LC}_{\mathrm{f}}$} & $\mathrm{SBR}$ & $\mathrm{qCO}_{2}$ & $\mathrm{DEN}$ & $\mathrm{RICH}$ & $\mathrm{DIV}$ & $\mathrm{UNIF}$ \\
\hline 6 DBP & $164.60 \mathrm{~b}$ & $95.00 \mathrm{~b}$ & $0.69 \mathrm{~b}$ & $4.40 \mathrm{bc}$ & $44.40 \mathrm{~b}$ & $2.30 \mathrm{c}$ & $0.16 \mathrm{~b}$ & $0.36 \mathrm{~b}$ \\
117 DAP & $310.90 \mathrm{a}$ & $137.40 \mathrm{a}$ & $0.39 \mathrm{~b}$ & $1.33 \mathrm{c}$ & $97.20 \mathrm{~b}$ & $2.25 \mathrm{c}$ & $0.14 \mathrm{~b}$ & $0.30 \mathrm{~b}$ \\
$215 \mathrm{DAP}$ & $97.80 \mathrm{c}$ & $54.80 \mathrm{c}$ & $0.52 \mathrm{~b}$ & $8.48 \mathrm{~b}$ & $382.40 \mathrm{~b}$ & $6.35 \mathrm{~b}$ & $0.53 \mathrm{a}$ & $0.67 \mathrm{a}$ \\
354 DAP & $101.40 \mathrm{c}$ & $143.20 \mathrm{a}$ & $1.26 \mathrm{a}$ & $19.31 \mathrm{a}$ & $945.60 \mathrm{a}$ & $9.45 \mathrm{a}$ & $0.69 \mathrm{a}$ & $0.70 \mathrm{a}$ \\
\hline
\end{tabular}

Averages followed by different letters in the column differ significantly among themselves by the Tukey test $(\mathrm{P}<0.05)$

green manure mix favored higher levels of soil microbial biomass and labile carbon of fumigated soil, through the improvement in the chemical and physical conditions provided by the incorporation of plant residues. Similar results were obtained by Xavier et al. (2006), who evaluated the microbial biomass in soils under organic and conventional farming systems in Ceará State, Brazil, and noted that the organic management contributed to the maintenance and recovery of microbial biomass. Studies conducted in Argentinean and Brazilian soils using soil microbial biomass carbon and labile carbon of fumigated soil founded a significant correlation between soil microbial biomass carbon and labile carbon of fumigated soil (DE-POLLI et al., 2007), the same result observed in this study, which may contribute to the evidence that labile carbon of fumigated soil can be a sensitive and promising indicator for revealing changes in soil quality, as reported by Souza et al. (2008) and Zou et al. (2005).

In contrast, soil basal respiration and metabolic quotient continued to increase significantly until 354 days after planting. At this time, when the highest levels of $\mathrm{CO}_{2}$ soil evolution were seen, soil microbial biomass carbon and labile carbon of fumigated soil levels were lower, which provides evidence of an inversely proportional response among these attributes.

This result is supported by the negative correlation observed between soil microbial biomass with soil basal respiration and metabolic quotient, indicating that the conditions that favored high soil microbial biomass were unfavorable to soil basal respiration and metabolic quotient. Additional evidence comes from the fact that the highest negative correlation was observed between soil microbial biomass and metabolic quotient (TAB. 2). Soil microbial biomass carbon was positively correlated to labile carbon of fumigated soil. A positive, but weak correlation was observed between labile carbon of fumigated soil with soil basal respiration and metabolic quotient ( 0.31 and 0.06 , respectively).
It is probable that after the third collection, the lack of continued incorporation of organic residues associated with less soil coverage had a negative influence on soil microbial biomass carbon. According to Matsuoka et al. (2003), practices such as mulching promote increased soil biomass.

In Figures $2 \mathrm{~A}$ and $3 \mathrm{~A}$, the length of the arrow indicates the change in soil attributes (arrows) in terms of the time of sample collections (numbers). This length is proportional to the correlation of the characteristic with the axes, and its importance in the explanation of the variance projected in each axis of the analysis. This analysis made it possible to detect groupings in terms of the time of sample collection (dots), it having been observed that the sum of the two canonical axes explained $86 \%$ (FIG. 2B) and $92 \%$ (FIG. 3B) of the total variation in the first two components, when comparing bioindicators with the period for soil collection (6 days before planting, 117, 256 and 354 days after planting).

There was the formation of two groupings: soil basal respiration and metabolic quotient, which was adjusted to the collections undertaken at 256 and 354 days after planting, to the left of the Figure $2 \mathrm{~B}$, while the soil microbial biomass and the labile carbon of fumigated soil were adjusted to the right, in consonance with the

Table 2 - Matrix of correlation among soil microbial biomass carbon (SMBC), soil basal respiration (SBR), metabolic quotient $\left(\mathrm{qCO}_{2}\right)$ and labile carbon of fumigated soil $\left(\mathrm{LC}_{\mathrm{f}}\right)$ evaluated during the green manure mix-melon crop succession in the municipality of Juazeiro, Bahia State, Brazil

\begin{tabular}{lcccc}
\hline & SMBC & SBR & $\mathrm{qCO}_{2}$ & $\mathrm{LC}_{\mathrm{f}}$ \\
\hline $\mathrm{SMBC}$ & 1.00 & -0.23 & -0.62 & 0.51 \\
$\mathrm{SBR}$ & - & 1.00 & 0.55 & 0.31 \\
$\mathrm{qCO}_{2}$ & - & - & 1.00 & 0.06 \\
$\mathrm{LC}_{\mathrm{f}}$ & - & - & - & 1.00 \\
\hline
\end{tabular}




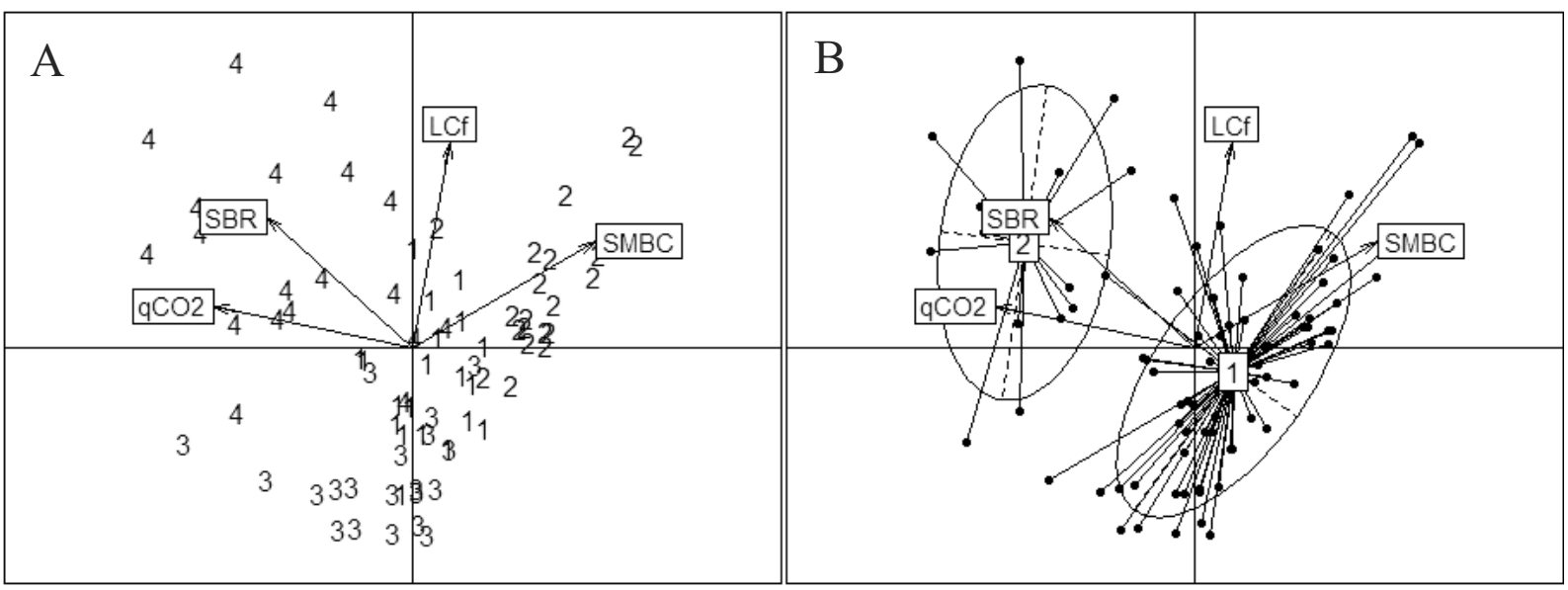

Figure 2 - 2A) Principal component analysis among soil microbial biomass carbon (SMBC), soil basal respiration (SBR), metabolic quotient $\left(\mathrm{qCO}_{2}\right)$ and labile carbon of fumigated soil $\left(\mathrm{LC}_{\mathrm{f}}\right)$ at 6 days before (1), and 117 (2), 256 (3) and 354 days after planting (4). 2B) Analysis of grouping among soil microbial biomass carbon (SMBC), soil basal respiration (SBR), metabolic quotient $\left(\mathrm{qCO}_{2}\right)$ and labile carbon of fumigated soil $\left(\mathrm{LC}_{\mathrm{f}}\right)$ at 6 days before and 117 days after planting (1) and 256 and 354 days after planting (2). The percentage of explanation of the variation in the original data from the first two principal components, in both cases, was $86 \%$

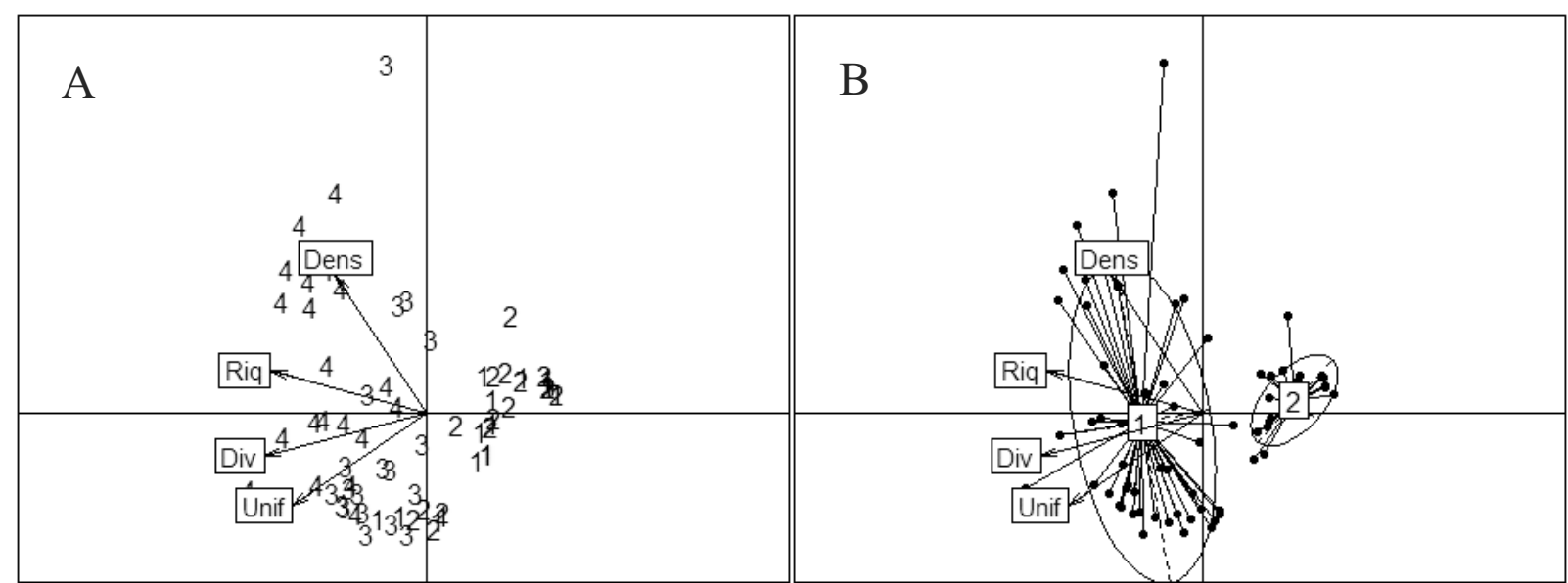

Figure 3 - 3A) Principal component analysis among density, richness, diversity and uniformity at 6 days before (1), and 117 (2), 256 (3) and 354 days after planting (4). 3B) Analysis of grouping among density, richness, diversity and uniformity at 256 and 354 days after planting (1) and 6 days before and 117 days after planting (2). The percentage of explanation of the variation in the original data from the first two principal components, in both cases, was $92 \%$

collections undertaken 6 days before planting and, principally, 117 days after planting. The labile carbon of fumigated soil contributed more to the second principal component, as can be seen from its vertical position in relation to the $\mathrm{Y}$ axis of the same figures.

Soil conditions favored the remobilization of carbon into the atmosphere in the form of $\mathrm{CO}_{2}$ previously stored in the microbial biomass and in organic matter, and contributed to an increase of the microbial stress. This microbial stress was indicated by the high metabolic quotient, since to the extent that the microbial population becomes more efficient, less carbon is lost as $\mathrm{CO}_{2}$ through respiration, and a higher proportion of carbon is incorporated into the microbial tissue (GAMA-RODRIGUES et al., 2005). In tropical soils, the loss of carbon with the cultivation of soils is more accelerated (MIELNICZUK et al., 2003), and the absence of conservationist management may have increased this loss.

It is worth highlighting the importance of microbial activity in the rapid transformation of organic residues into plant nutrients (TU; RISTAINO; HU, 2006). In this 
Table 3 - Matrix of correlation among density, richness, diversity and uniformity of edaphic macrofauna evaluated during the green manure mix-melon crop succession in the municipality of Juazeiro, Bahia State, Brazil

\begin{tabular}{ccccc}
\hline & Density & Richness & Diversity & Uniformity \\
\hline Density & 1.00 & 0.61 & 0.29 & 0.06 \\
Richness & - & 1.00 & 0.82 & 0.51 \\
Diversity & - & - & 1.00 & 0.84 \\
Uniformity & - & - & - & 1.00 \\
\hline
\end{tabular}

study, the soil basal respiration reinforces this postulate, considering that at 215 days after planting the soil was covered with melon crop, microbial activity may have positively contributed to the mineralization of nutrients. In this sense, soil basal respiration is one of the main measurements for evaluating microbial activity of the soil, with the quantity of $\mathrm{CO}_{2}$ released being indicative of the soil labile carbon. Nevertheless, the interpretation of the results of microbiological activity should be made with caution, since elevated values of respiration do not always indicate desirable conditions; a high rate of respiration may mean, in the short term, loss of soil organic carbon to the atmosphere (PARKIN; DORAN; FRANCO-VIZCAÍNO, 1996).

In contrast to the microbial attributes, the edaphic macrofauna presented a different standard of response; the values of density, richness, diversity and uniformity were systematically improved with the passage of time (TAB. 1). At 215 days after planting, a significant improvement of ecological indicators began, notably in diversity and uniformity, while density and richness presented apparent quantitative gains. This period was preceded by the greatest rainfall, which may have contributed to the occurrence of edaphic macrofauna (FIG. 1) (LEITÃO-LIMA; TEIXEIRA, 2002). According to Lavelle et al. (1992), in tropical regions, soil macrofauna should be sampled during the rainy season, when the temperature and humidity climatic factors are not yet limiting factors. Finally at 354 days after planting, the results indicate a higher uniformity of distribution of ants (Formicidae) and beetles (Coleoptera) among the treatments with green manure mix and, in a parallel way, a higher occurrence of groups which until then were little present, such as Isopoda (woodlice), and Diplopoda (millipedes). This period was marked by increases in density, richness, diversity and uniformity. Although the presence of beetles has been associated with improvement of the soil macrofauna (KITAMURA et al., 2008), in this experiment, the apparent improvement of edaphic macrofauna was accompanied by a decrease in the number of beetles.

There was a formation of two distinct groups for edaphic macrofauna: density, richness, diversity and uniformity, which were adjusted to the collection undertaken at 215 and 354 days after planting, to the left of Figures $3 \mathrm{a}$ and $3 \mathrm{~b}$; whereas to the right, they were adjusted to the collections of 6 days before planting and 117 days after planting. In regard to the correlations, Table 3 shows that they were positive among all the variables of edaphic macrofauna. The strongest correlations were obtained between diversity and richness, and between uniformity and diversity ( 0.82 and 0.84 , respectively). As the diversity of a group increases, the richness associated with it also increases, and the distribution of individuals through the groups becomes more balanced (uniformity increases), because a more favorable environment presupposes a higher diversity of groups.

It is possible to perceive the adjustment of Hymenoptera, Blattaria, Psocoptera, Dermaptera, Oligochaeta, Thysanoptera, Formicidae and Isopoda at 354 days after planting (FIG. 4), this result being corroborated by the diversity, richness and density presented in Table 1.

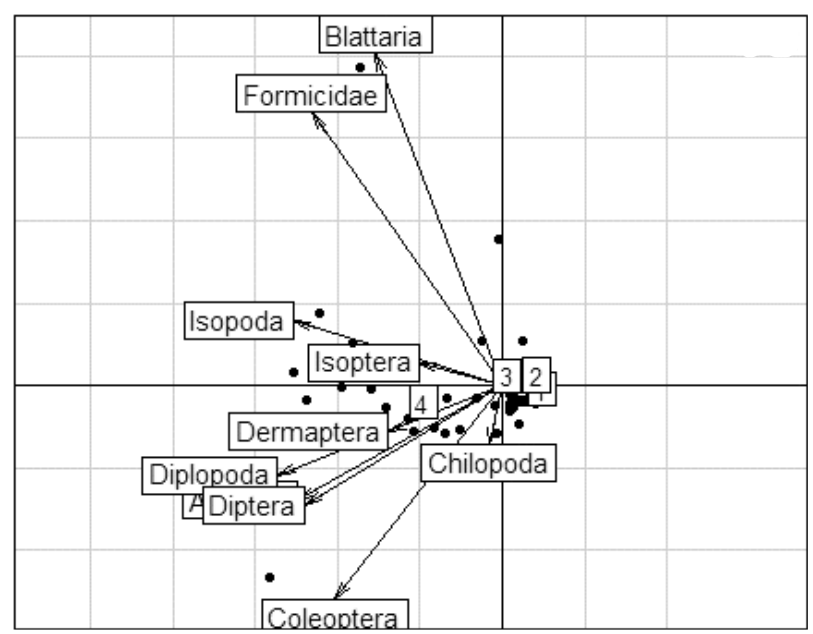

Figure 4 - Principal components analysis of the groups founded at 6 days before planting (1), and 117 (2), 256 (3) and 354 days after planting (4). The percentage of explanation of the variation in the original data was $42 \%$ for two principal components 
Table 4 - Average relative distribution (\%) of the main groups of edaphic macrofauna at 6 days before and 117, 215 and 354 days after green manure mix planting in soil subjected to green manure mix-melon crop succession in the municipality of Juazeiro, Bahia State, Brazil

\begin{tabular}{ccccccc}
\hline Days & & \multicolumn{5}{c}{ Groups } \\
\hline \multirow{2}{*}{6 DBP } & Coleoptera & Formicidae & Oligochaeta & Diptera & Araneae & Others* \\
& 40.3 & 18.6 & 14.8 & 7.4 & 6.1 & 13.0 \\
\hline \multirow{2}{*}{117 DAP } & Formicidae & Coleoptera & Araneae & Blattaria & Chilopoda & Others \\
& 50.4 & 22.0 & 6.9 & 6.8 & 5.6 & 8.3 \\
\hline \multirow{2}{*}{215 DAP } & Formicidae & Coleoptera & Diplopoda & Dermaptera & Isopoda & Others \\
& 47.9 & 21.9 & 6.6 & 5.2 & 5.0 & 13.5 \\
\hline \multirow{2}{*}{354 DAP } & Formicidae & Isopoda & Diplopoda & Coleoptera & Thysanoptera & Others \\
& 34.2 & 21.8 & 20.5 & 5.6 & 4.3 & 13.7 \\
\hline
\end{tabular}

*Others: Groups with a frequency less of than 4\% (Diplura, Hymenoptera, Lepidoptera, Symphyla, Isoptera, Psocoptera, Gastropoda, Orthoptera, Homoptera, Hemiptera and Scorpionidea)

The results allow one to infer that the ants were most favored throughout almost the entire period analyzed and this result may be correlated with the ease of locomotion associated with these animals (PARR et al., 2007), as well as the facility of adaptation to local conditions (SILVA et al., 2006). On the other hand, the presence of ants in agricultural areas has been associated with lower quality of soil cover (PARR et al., 2007), which indicates that all the environments in the study may be in quite similar states of conservation.

These results are corroborated by Table 4, which indicates that ants and beetles were the organisms most found, followed by Isopoda, Diplopoda and Araneae. At 6 days before green manuring, the beetles represented $40 \%$ of total organisms, whereas, at 117, 215 and 354 days after planting, the ants came to be dominant, followed by the beetles, Isopoda and Diplopoda. It is probable that organic farming practices have favored the edaphic macrofauna, as was observed by Silva et al. (2006) in a no-till system, which allowed higher diversity of groups. When studying a perennial legume, it was observed that the presence of legumes increased soil macrofauna density (DIAS et al., 2006), showing that plant diversity favors soil macrofauna.

\section{Conclusions}

1.Edaphic macrofauna, soil microbial biomass, soil basal respiration, metabolic quotient and labile carbon of fumigated soil levels changed significantly in relation to the time of sample collection;

2. Soil microbial biomass carbon was inversely correlated with soil basal respiration and metabolic quotient;
3. At354 days after planting, the edaphic macrofauna presented the highest density, richness, diversity and uniformity;

4. Ants and beetles were most abundant in the areas studied.

\section{References}

ALMEIDA, D. L. et al. Agricultura orgânica instrumento para a sustentabilidade dos sistemas de produção e valoração de produtos agropecuários. Seropédica: EMBRAPA Agrobiologia, 2000. 22 p. (Documentos, 122).

ALMEIDA-CORTEZ, J. S. et al. Caatinga. São Paulo: HARBRA, 2007. $64 \mathrm{p}$.

ANDERSON, J. D.; INGRAM, J. S. I. Tropical soil biology and fertility: a handbook of methods. 2. ed. Wallingford: CAB International, 1993. $171 \mathrm{p}$.

ANDERSON, T. H.; DOMSCH, K. H. Application of ecophysiological quotients $\left(\mathrm{qCO}_{2}\right.$ and $\left.\mathrm{qD}\right)$ on microbial biomass from soils of different cropping histories. Soil Biology and Biochemistry, v. 22, n. 02, p. 251-255, 1990.

DE-POLLI, H. et al. Alta correlación entre el "pool" de carbono lábil por fumigación con cloroformo-extracción (carbono de biomasa microbiana plus) y carbono de biomasa microbiana en suelos de Argentina y Brasil. Ciencias del Suelo, v. 25, n. 01, p. 15-22, 2007.

DE-POLLI, H.; GUERRA, J. G. M. Carbono, nitrogênio e fósforo da biomassa microbiana do solo. In: SANTOS, G. A. et al. (Eds.) Fundamentos da matéria orgânica do solo - Ecossistemas tropicais e subtropicais. 2. ed. Porto Alegre: Metrópole, 2008. p. 263-276.

DIAS, P. F. et al. Árvores fixadoras de nitrogênio e macrofauna do solo em pastagem de híbrido de Digitaria. Pesquisa Agropecuária Brasileira, v. 41, n. 06, p. 10151021, 2006. 
DORAN, J. W. Soil health and global sustainability: translating science into practice. Agriculture, Ecosystems and Environment, v. 88, n. 02, p. 119-127, 2002.

DORAN, J. W. Soil microbial and biochemical changes associated with reduced tillage. Soil Science Society American Journal, v. 44, n. 04, p. 765-771, 1980.

EMPRESA BRASILEIRA DE PESQUISA AGROPECUÁRIA (EMBRAPA). Centro Nacional de Pesquisa de Solos. Manual de métodos de análise de solo. Rio de Janeiro: EMBRAPA Solos, 1997. $212 \mathrm{p}$.

FRANCHINI, J. C. et al. Microbiological parameters as indicators of soil quality under various soil management and crop rotation systems in Southern Brazil. Soil and Tillage Research, v. 92, n. 01/02, p. 18-29, 2007.

GAMA-RODRIGUES, E. F.. et al. Nitrogênio, carbono e atividade da biomassa microbiana do solo em plantações de eucalipto. Revista Brasileira de Ciência do Solo, v. 29, n. 06, p. 893-901, 2005.

HERDJANIA, V. L. et al. Indicadores de qualidade do solo em sistemas de cultivo orgânico e convencional no semi-árido cearense, Revista Brasileira de Ciência do Solo, v. 31, n. 05, p. 1085-1098, 2007.

JANZEN, D. H. Florestas tropicais secas: o mais ameaçado dos ecossistemas tropicais. In: WILSON, E. O. (Ed.) Biodiversidade. Rio de Janeiro: Nova Fronteira, 1997. p. 166-176.

KITAMURA, A. E. et al. Recuperação de um solo degradado com a aplicação de adubos verdes e lodo de esgoto. Revista Brasileira de Ciência do Solo, v. 32, n. 01, p. 405-416, 2008.

LAVELLE, P. et al. The impact of soil fauna on the properties of soils in the humid tropics. In: SANCHEZ, P. A.; LAL, R. (Eds.). Myths and science of soils of the tropics. Madison: Soils Science Society of America, 1992.

LEITÃO-LIMA，P. S.; TEIXEIRA， L. B. Macrofauna do solo em capoeiras natural e enriquecidas com leguminosas arbóreas. Belém: EMBRAPA, 2002. 3 p. (Comunicado Técnico, 62).

MAGURRAN, A. E. Ecological diversity and its measurement. New Jersey: Princeton University, 1988. 179 p.

MARTINS, L. M. V. Comportamento de estirpes de rizóbio introduzidas como inoculantes para caupi (Vigna unguiculata) em solos do semi-árido brasileiro. 2003. 66 f. Tese (Doutorado em Ciências do Solo) - Universidade Federal Rural do Rio de Janeiro, Seropédica, 2003.

MATSUOKA, M. et al. Biomassa microbiana e atividade enzimática em solos sob vegetação nativa e sistemas agrícolas anuais e perenes na região de Primavera do Leste (MT). Revista Brasileira de Ciências do Solo, v. 27, n. 03, p. 425-433, 2003.

MIELNICZUK, J. et al. Manejo de solo e culturas e sua relação com os estoques de carbono e nitrogênio do solo. In: CURI, N. et al. Tópicos em ciência do solo. Viçosa, MG: Sociedade Brasileira de Ciência do Solo, 2003. v. 03. p. 209-248.

PARKIN, T. B.; DORAN, J. W.; FRANCO-VIZCAÍNO, E. Field and laboratory tests of soil respiration. In: DORAN, J. W.; JONES, A. (Ed.). Methods for assessing soil quality. Madison: Soil Science Society of America, 1996. p. 231-245.

PARR, C. L. et al. Savanna fires increase rates and distances of seed dispersal by ants. Oecologia, v. 151, n. 01, p. 33-41, 2007.

PASSOS, O. S. et al. Certificação e diversificação da citricultura do nordeste brasileiro. Cruz das Almas: EMBRAPA, 2004. 7 p. (Comunicado Técnico, 101).

PIMENTEL, M. S. Utilização de bioindicadores sob diferentes coberturas do solo e avaliação de sua sustentabilidade. 2005. 116 f. Tese (Doutorado em Fitotecnia) - Universidade Federal Rural do Rio de Janeiro, Seropédica, 2005.

R DEVELOPMENT CORE TEAM. R: a language and environment for statistical computing. Viena: R Foundation for Statistical Computing, 2009. Disponível em: $<$ http://www.Rproject.org.>. Acesso em: 26 jun. 2009.

SILVA, R. F. et al. Macrofauna invertebrada do solo sob diferentes sistemas de produção em Latossolo da Região do Cerrado. Pesquisa Agropecuária Brasileira, v. 41, n. 04, p. 697-704, 2006.

SILVA, M. B. et al. Atributos biológicos do solo sob influência da cobertura vegetal e do sistema de manejo. Pesquisa Agropecuária Brasileira, v. 42, n. 12, p. 1755-1761, 2007.

SOUZA, R. A. de. et al. Avaliação qualitativa e quantitativa da microbiota do solo e da fixação biológica do nitrogênio pela soja. Pesquisa Agropecuária Brasileira, v. 43, n. 01, p. 71-82, 2008.

Stotzky, G. Microbial respiration. In: Black, C. A. et al. (Eds.). Methods of soil analysis. Madison: American Society of Agronomy, 1965. Part 2, p. 1550-1572. (Agronomy, 9) TU, C.; RISTAINO, J. B.; HU, S. Soil microbial biomass and activity in organic tomato farming systems: effects of organic inputs and straw mulching. Soil Biology and Biochemistry, v. 38, n. 02, p. 247-255, 2006.

XAVIER, F. A. S. et al. Biomassa microbiana e matéria orgânica leve em solos sob sistemas agrícolas orgânico e convencional na Chapada da Ibiapaba - CE. Revista Brasileira de Ciências do Solo, v.30, n. 02, p. 247-258, 2006.

ZOU, X. M. et al. Estimating soil labile organic carbon and potential turnover rates using a sequential fumigation-incubation procedure. Soil Biology and Biochemistry, v. 37, n. 10, p. 1923-1928, 2005. 